\title{
Література:
}

1. Волобуєва О. Ф. Психологічні особливості сприйняття та розуміння текстів іноземною мовою. Вісник Київського начіонального університету імені Тараса Шевченка. 2015. С. 14-17.

2. Демчук Н. Р. Науковий текст як стратегічний засіб наукової комунікації (до проблеми редакційного опрацювання). Молодий вчений. 2016. № 9. С. 325-331.

3. Козловська Л. С., Терещенко С. І. Текст як основний компонент професійного економічного дискурсу (лінгвометодичний аспект). Культура народов Причерноморья. 2004. № 49, Т. 2. С. 174-176.

4. Черненко Н. М. Работа с текстами научной коммуникации (в системе вузовской подготовки студентов технических специальностей) : дис. ... канд. пед. наук : 13.00 .02 : Ярославль, 2004. 215 с.

5. Яхонтова Т. В. Лінгвістична генологія наукової комунікації : монографія. Львів : ВЦ ЛНУ ім. І. Франка, 2009. 420 с.

DOI https://doi.org/10.30525/978-9934-588-90-7-2

\section{ХУДОЖЕСТВЕННЫЙ КОНЦЕПТ «ОРЕЛ» В ЛИРИКЕ М. И. ЦВЕТАЕВОЙ}

\author{
Габидуллина А. Р.
}

доктор филологических наук,

профессор кафедры языкознания и русского языка

Горловский институт иностранных языков

ГВУЗ «Донбасский государственный педагогический университет»

Ладонина В. Д.

студентка IV курса

Горловский институт иностранных языков

ГВУЗ «Донбасский государственный педагогический университет»

г. Бахмут, Донеикая область, Украина

Орел (орлица) - это орнитоним, который играет важную роль в поэтике выдающегося поэта XX века М. И. Цветаевой. Данный художественный концепт обладает в ее стихах множеством смыслов как традиционных, так и индивидуально-авторских.

Мировая литература и фольклор ассоциируют орла с величием, властью, господством, отвагой, вдохновением, духовным подъемом [6]. 
Для М.И. Цветаевой это царская птица. В стихотворении «Выше глаз уходят горы...» орлом назван царевич («Обнял девушку ияаревич - Что орел ширококрыльий»). Царь-девица из одноименного цикла - это идеальный женский образ, амазонка, в которой подчеркивается андрогинность: «Брови сильные стянув, / Взор свой - как орлица клюв - / $B$ спящего вонзает». Прослеживаются мотивы силы, свободы, стихии и своеволия. Она спасает слабого возлюбленного, относится к нему поматерински («Над орленком своим - орлища, / Над иаревичем - Царьдевица»). Трагедия героини в том, что сильная женщина влюбляется в музыканта, поэта, видит ровней, но его преданность искусству как явлению небесному оказывается несовместимой с любовью земной. «Слабость» царевича трагически побеждает силу Царь-девицы: «Вихрьжар-град-гром была, - За все наказана! Войска в полон брала, Былинкой связана!» [1].

В стихотворении «Казацкая, татарская...» орлом называется Матвей Гагарин - неоднозначная фигура в истории Российской империи. Соратник Петра Великого, «губернатор всея Сибири», талантливый организатор, умный, деятельный, энергичный человек - с одной стороны, коррупционер и взяточник - с другой: «Орел-губернатор! / Тот самьій орел, / От города на три / Верстищи Тобол / Отведший и в высшей / Коллегии птии / За взятки повисший». Концепт «орел» содержит здесь заметную ироническую окраску.

Орел как 'крупная сильная хищная птица семейства ястребиных, живущая в гористых или степных местностях' [2], является во многих культурах символом богов и их окружения. Он равен по своей мощи и архангелам, и серафимам, и ангелам [4]: «Серафим - на орла! Вот бой! Примешь вызов? - Летим за тучи!» («Серафим - на орла! Вот бой!»). В облике Анны Ахматовой М.И. Цветаева обнаруживает что-то «от ангела и от орла» («Еще один огромный взмах...»). В 1918 году Марина Ивановна считает, что только Петр Великий может навести порядок в стране, разрушенной революцией и гражданской войной. Это мы видим в образах архангела и орла: «Народ обезглавлен и ждет главы. / Уж воздуху нет ни в чьей груди. / Архангел! - Орёл! - Гряди!» («Орёл и архангел! Господень гром!»).

В цикле «Разлука» обыгрывается античный сюжет похищения зевесовым орлом возлюбленного - Ганимеда. Прекрасный юноша, сын одного из троянских царей и бессмертной нимфы, по прихоти бога перенесен на Олимп для того, чтобы стать виночерпием. Правда, жертва орла у Цветаевой - «ягненок крохотный - любовь»: «B орлином грохоте - / О клюв! О кровь! / - Ягненок крохотный / Повис - Любовь!». В словаре символов Д. Тресиддера описывается способность орла смотреть на солнце не мигая. Это помогает ему переносить души на 16 
небеса [6]. По мнению О. А. Скриповой, похищение возлюбенного может трактоваться именно так. Цикл «Ремесло» заканчивается «устремлением самой лирической героини в «орлиную высь», обретением крыла и сражением с богами за любовь» [5].

Свойство птицы безболезненно смотреть на солнце обыгрывается и в стихотворении М. И. Цветаевой, обращенном к О. Мандельштаму: «Лети, молодой орёл, / $\mathrm{Tbl}$ солнце стерпел, не щурясь» («Никто ничего не отнял!..»). Лирическая героиня стихотворения считает, что истинная любовь дает человеку возможность преодолеть все преграды, среди которых - расстояние в сотни верст, в сотни лет. Лирические Я и ТЫ мыслятся здесь как орлята - еще неопытные птенцы. Цветаева называет адресата «молодым Державиным». Спустя много лет в статье «Поэтальпинист» она объяснит этот образ тем, что у Мандельштама Державин именно - традиция, словесная и даже словарная. Употребление имени Гавриила Романовича в данном контексте переносное, символ большого классического поэта. На этом фоне свои стихи лирическая героиня Цветаевой называет «невоспитанными», т. е. нарушающими законы жанра, не классическими, нетрадиционными. Полет молодого орла лирическая героиня называет страшным, ведь именно она «ставит предел полету орла своим поцелуем, предел, о которыйтот должен разбиться или который должен разбить; полет страшен для лирического Я, так как он бесповоротно разъединяет его с лирическим ТЫ-ВЫ...» [3, с. 77]. Почему разлука неизбежна? Потому что лирическая героиня сильнее любимого, она давит на него: «Юный ли взгляд мой тяжел». Разные характеры, разная сила воли, разные позиции в подходе к творчеству - вот что разъединяет молодых орлов. Их прощание - неизбежно.

От «орла залетного» рождается герой поэмы «Егорушка»: «Оборонил орел залетный перышко./ Родился на свет Егорий-свет-Егорушка». Подобно многим сказочным персонажам, он наделяется необычными чертами: вскормлен волчицей, как Ромул и Рем, и дружит с волчонком (подобно Ивану-царевичу); наделен недюжинной физической силой; постоянно подвергается испытаниям (больше нравственным, чем физическим): отказывается от райских яблок, потрясенный слезинкой ребенка, защищает ягненка от стаи волков; остается честным, став приказчиком, отдает товар нищим и обездоленным. В «нерусской стороне», Серафим-граде, отзывается на зов о помощи («Нет для меня величия, коли кто на помощьь кличет»). Сын орла одерживает победу на Змеем, Злым царем, пытается сохранить Голубиную книгу судеб. Автор любуется своим героем, восхищается его героическим характером, видит в нем мужчину своей мечты: «Эх, кабы мне, Маринушке, / Да тебя, Егорушку!». 
Итак, орел наделен у М.И. Цветаевой такими чертами, как отвага, свободолюбие, власть, физическая сила, одиночество и величие. Он важнейший символ, эмблема всевидящих богов неба и солнца, правителей и воинов.

\title{
Литература:
}

1. Зуева-Озкан В. Б. Образ воительницы в поэме «Царь-девица»: к вопросу о характерологии М. Цветаевой. Новый филологический вестник. 2016. № 4 (39). С. 71-86

2. Ефремова. Т. Ф. Современный толковый словарь русского языка. Москва: АСТ, 2006. 976 с.

3. Кудрявцева Е. Л. Опыт семантического анализа стихотворения Марины Цветаевой «Никто ничего не отнял» на спецсеминаре по лингвопоэтике. Констрантин Бальмонт. Марина Цветаева и хулдожественные искания $X X$ века: межвузовский сборник научных трудов. Иваново : ИГК, 1999. Вып. 4. С. 192-194

4. Лаврова Е. Л. Художественный мир М. Цветаевой : поэтика стихий : монография. Горловка : Коллегия, 2014. 323 с.

5. Скрипова О.А. «Быть голубкой его орлиной»: образы птиц в книге стихов М. Цветаевой «Ремесло». Филологический класс. 2019. № 2. C. $207-212$.

6. Трессидер Д. Словарь символов. М. : ФАИР-ПРЕСС, 1999. 448 с.

DOI https://doi.org/10.30525/978-9934-588-90-7-3

\section{PRINCIPLES OF IDIOM DESCRIPTION AS A METHODOLOGICAL BASIS OF MODERN DIALECTOLOGICAL DESCRIPTION}

\author{
Hromko T. V. \\ Candidate of Philology, \\ Associate Professor at the Ukrainian Language Department \\ Volodymyr Vynnychenko Central Ukrainian State Pedagogical University \\ Kropyvnytskyy, Ukraine
}

Description as a descriptive study of a particular usus in modern linguistics demonstrates the unlimitedness of the issues and methods of presentation of the material. Such studies of the idiom are (1) the most detailed source of information about the composition of dialect vocabulary and features of its 